\title{
From Individual to Corporate Praxis: A Systemic Re-Imagining of Religious Education
}

\author{
Barbara J. Fleischer, Ph.D. \\ Loyola University New Orleans
}

\section{Religious Education Association/Association of Professors and Researchers in Religious Education Joint Meeting, November, 2003}

When the Religious Education Association (REA) was founded in 1903, its progressivist proponents were already leaning heavily into experiential, participative, and action-oriented education. John Dewey, pragmatist philosopher and a major advocate of learning-by-doing models of education, delivered the REA's first keynote address and brought many of his progressivist ideas into the shaping of the incipient REA. Similarly, George Albert Coe, also a highly influential co-founder of the REA, championed inductive methods of education and, particularly, of religious education (Boys, 1989, 46-54). Consequently, the initial purpose of the REA reflected the progressivist faith in emerging educational paradigms not only for promoting individual growth but also for transforming society and proposed what David Tracy would later call a "mutually critical correlation" $(1975,23)$ between two focal areas: education and religious wisdom traditions. The originating aim of the REA was "To inspire the religious focus of our country with the religious ideal; to inspire the educational forces of our country with the religious ideal; and to keep before the public mind the ideal of moral and religious education and the sense of its need and value" (REA, 2).

Concern for the public dimension of faith life and the culturally transformative potential of religious education marked much of the early progressivist writings in the emerging religious education field. Coe raised the crucial world-making question when he wrote, "Shall the primary purpose of Christian education be to hand on a religion, or to create a new world?" $(1929,28)$ Religiously, Coe stood staunchly against the privatization of faith and reminded Christians that their faith life involved co-creating a more human and compassionate society. Christian life, and therefore Christian religious education, required a constitutive dimension of public action.

Thomas Groome and other religious educators have continued the emphasis on praxis, or reflective action, as the heart of Christian religious education. Groome's now classic work, Christian Religious Education (1980), presents a deep and clear rationale for shared Christian praxis, as well as a methodology for implementing it in a variety of educational settings. Groome states simply that the purpose of Christian religious education is "to enable people to live as Christians, that is, to live lives of Christian faith" $(1980,34)$ and, further that the purpose of Christian faith is ultimately service to the Kingdom, or reign, of God (34). The religious educator leads people into authentic service to God's reign by engaging them in an actionreflection rhythm of Christian praxis.

While praxis-oriented educational methodologies, involving experiential, dialogical, and action dimensions, have become nearly normative in adult Christian religious education, an individualist framework still colors many of the approaches involved. Most approaches, such as many of the applications of Groome's shared Christian praxis methods or those based on Mezirow's transformative education, involve participants in praxis discussions where they share 
their present action in the world and reflect together on the Christian story and its responsive vision, yet the actions identified tend to be individual rather than communal endeavors.

Consequently, the praxis movement of learning groups is one of gathering for reflection and then being "sent" individually for action. While this is one positive approach to religious education, the complexities of issues that Christians are called to address, if Christian communities are to be truly transformative catalysts in the world, require models of communal or corporate praxis in which entire communities engage in action as well as reflection together on their common praxis.

This paper will explore some of the historical underpinnings of religious education models that emphasize a corporate approach to praxis-oriented education and will also offer new possibilities for a systemic re-imagining of religious education. The systemic approach proposed draws largely from the literature on "learning organizations" and will call for a model that weaves religious education into the fabric of communal pastoral planning and action, as a collaborative venture with other ministries in congregational life.

\section{The Call for Communities in Praxis}

\section{Christian Mission and the Reign of God}

In Christian religious education, the call for communal praxis in the world is first of all rooted in the acknowledgement that churches exist to further and continue the mission of Jesus in proclaiming and ushering in the reign of God. The Hebrew scriptures are replete with images of the reign of God that speak not only of a profound shalom among nations and the human community but also of a restoration and healing of the entire natural world (e.g., Isa. 41:17-20; 61:17; Psalm 104). In the Christian gospels, the theme of the reign of God is central in the preaching and reconciling actions of Jesus. Discipleship calls for the courageous creation of an expanding, widely inclusive community of faith and gratitude, despite the personal costs involved in shattering social customs and structures of exclusion.

Thomas Groome points out that, following centuries of focus on issues of doctrine and orthodoxy, the past two hundred years have experienced a growing awareness of missionconsciousness among Christian churches $(1980,43)$. Though awareness of mission and service has always been present in Catholic religious orders and Protestant mission services, the primary religious education model in previous centuries was one of religious instruction of the laity for the purpose of transmitting the faith tradition. A turning point in religious education approaches can be traced back to the Christian nurture approach of Horace Bushnell (1802-1876) who emphasized a gradual and contextual development of children into the values and virtues of mature Christian living (Boys, 1989, 41-41) and, in Catholic circles, to the beginnings of papal writings on contemporary social justice issues (Rerum Novarum, 1891). In the latter half of the twentieth century, liberation theologies rang out a resounding critique of theologies and models of religious education that emphasized inner and personal (or private) "growth" while ignoring action on behalf of the suffering of the world's poorest sectors. This call for a new emphasis on Christian praxis, however, hearkens well back into the nineteenth century. In speaking of the liberation/praxis approach to religious education, Jack Seymour and Donald Miller point out that its critique of religious instruction dates back to the 1860's. 
Liberation educators begin with the biblical promise and vision of the kingdom of God. This vision, combined with a social analysis, is to inspire the mission of the church.

...Traditional Christian education is criticized as deficient because it tends to deal with privatistic individualism and with unembodied content, both of which insulate church members from the harsh realities of the world.

This same critique was leveled at Christian education more than one hundred years ago when the Sunday school was transformed from a mission school for the poor and isolated into and educational agency for the church's members. In the 1860s, Henry Ward Beecher, the pastor of Plymouth Church in Brooklyn, pleaded with church leaders not to forget the original mission purpose of the Sunday school (Seymour and Miller, 1982, 25).

Mary Boys likewise points out that the early founders of the Religious Education Association, especially George Albert Coe, criticized "transmissive" models of religious education for their failure to incorporate a social vision in teaching. Coe called for an analysis of current social conditions and an educated responsiveness to the social order in light of Christian values (Boys, 1989, 52). His approach foreshadowed the liberationist approach to religious education that would emerge more fully in Third and Fourth World contexts. In the United States, praxis-oriented forms of religious education also continued to develop throughout the past century. Yet, as Seymour and Miller note, U.S. religious education continues to show individualist leanings and requires a more balanced attention to the social dimensions of Christian life $(1982,155)$. Their call for future development in religious education, over two decades ago, included the following exhortation:

Christian education must seek to recover its historic commitment to social transformation...Christian education must continue to address questions about the agenda for Christian mission and vocation---questions raised by the present situation of the world, with its hunger, oppression, and gap in wealth - and about how to speak the Christian message meaningfully and powerfully in this cultural context.

This does not mean that Christian educators must forget or ignore all they have learned about personal transformation. Yet it does mean that the individual agenda must be balanced with attention to the social context for learning, as well as with the place of Christian education in the mission of the church. Attention should be given to building an approach to Christian education which understands how persons are formed in a social context and how a responsible commitment to the wider world can be built (Seymour and Miller, 1982, 154-155).

Anne Streaty Wimberly, in her 2002 presidential address to the Association of Professors and Researchers in Religious Education, echoed the call for religious educators to become leaders and teachers of social change. She noted that at this time of unprecedented scientific and technological achievements, the world itself is increasingly becoming endangered as a life 
system $(2003,279)$, and she called for religious educators to contribute to "a sustainable communal and earth environment in which peace, love, justice, reconciliation, and the care of the environment reside" (277).

\section{The Complexities of Contemporary Social Structures}

A second compelling reason for emphasizing communal rather than individual Christian praxis in the world is that contemporary social problems involve complex networks of power systems, colluding large-scale institutions, and mega-structures. Trying to offer assistance to even one homeless person calls forth questions of mental health support systems, government funding for housing, social and health services, and lack of adequate insurance coverage for those marginalized in society. Assisting one person with multiple life issues can be overwhelming for an individual in praxis, and it can also lean into forms of paternalism/maternalism in offering assistance. One-on-one individual praxis is quite limited in what it can accomplish, especially if the goal is the transformation of social structures, as well as care for individuals.

In 1995, the Jesuit order gathered for its $34^{\text {th }}$ General Council of the Society of Jesus and set ministry priorities related to justice at the dawn of the new millennium. Their list included: working to end discrimination based on race, religion, gender, ethnic background or social class; working to counter growing poverty and hunger while material prosperity becomes ever more concentrated; insuring the basic human rights of all peoples, such as economic and social rights to the basic necessities of life and well-being, freedom of conscience and expression, and civil and political rights. They further called for the careful development of ethical guidelines for medical experimentation and genetic engineering, working to divert resources from war and the international traffic in arms towards providing for the needs of the poor, and balancing ecological harmony with a sustainable and equitable human economy (Articles 6-9). While many other issues could be added to this list, especially in light of the current U.S. "war on terrorism" and other international tensions, it already names a formidable task for transformation of the social order in light of gospel values. Only the concerted and networked effort of persons engaged in communal praxis will begin to make a difference in the face of the already wellorganized social systems that currently drive the workings of contemporary societies.

\section{Developing Communities in Praxis: the Small Christian Community Movement}

One model that would seem to offer hope for fostering communal praxis is the small Christian community movement that takes its lead from liberation-oriented Latin American communidades de base, where communal praxis is fostered and current social situations are read in light of gospel imperatives. The small Christian community movement in Latin America reflects a blending of what Seymour and Miller call the "faith community" and "liberation" models $(1982,16)$ of religious education, since scripture study takes place in a community of faith that reflects critically on implications of biblical texts for social action. In the light of biblical readings, community members discern together their communal response to the situations they face. In the United States, however, national research on small Christian communities in the Catholic context shows that communal reflection does not lead into communal action on a wide scale. In a national multi-faceted study funded Lilly Endowment, 
Bernard Lee and fellow researchers found little evidence of social outreach as a result of engagement with group scriptural reflections.

Both the survey data and the observations and interviews reveal that gathering is the most rewarding part of SCC experience, and that being sent, that is, social outreach, is a problematic dimension of the ecclesial reality of SCCs. And when being sent is operative, far more members understand that as the individual members of the community being sent, not the community as an entity...SCC membership does frequently raise social awareness, but falls short of social action (Lee, 2000, 94).

The exception to this national trend occurred among U.S. Hispanic/Latino small Christian communities. Most Hispanic/Latino communities involved entire households in a multigenerational small faith community (Lee, 2000, 109). Interestingly the researchers found that among Hispanics, small Christian community membership is much more organically connected to members' experience of church as well as to their social life than is true for any other groups studied (Lee, 2000, 110). Hispanic/Latino groups were also more than twice as likely to address social issues as a group than other non-Latino small Christian communities studied (94). The researchers attribute many of these results to cultural differences in how Latinos view themselves compared to other Euro-American groups. Citing recent sociological studies, Lee and his colleagues suggest that Latinos are sociocentric in nature; for them the basic unit of society is the group to which one belongs. Dominant U.S. culture, by contrast, tends to be more individualistic and contractual, so that group membership is perceived to happen by contractual arrangement (110-111). Theologian Roberto Goizueta argues that the relational nature of Hispanic culture, "where the person is viewed as intrinsically social," both emerges from and leads to communal praxis. The person's sense of selfhood arises from interactions and actions in community, and the deep caring for one another, along with concern engendered for the community's children, impels members to act together for social justice for the good of the community as a whole (77).

Such cultural underpinnings of basic notions of selfhood illustrate some of the obstacles religious educators face as they try to reclaim a socially transformative paradigm for religious education. Individualism embedded in the dominant culture of the United States often creates an obstacle to envisioning and carrying out communal praxis, though persons may be able to see the calls for social transformation and outreach found throughout the Scriptures and later Christian writings. The flesh seems to be weak in many U.S. contexts for moving toward concerted action for justice.

While small Christian communities in dominant U.S. culture show little movement toward action, church-based community organization efforts have shown some success in mobilizing faith communities to act for justice. Organizations such as those fostered by the Industrial Areas Foundation, founded by social activist Saul Alinsky, garner together the energy of Christian congregations, synagogues, mosques and other faith communities to address clearly identified issues with imagination and power. One example is the "Jeremiah" group in New Orleans, composed of over 40 congregations, who are addressing issues of housing, drug treatment programs, education, and employment in the greater metropolitan area. Their gathering premise begins with action in mind, rather than "faith-sharing," and participants learn a 
variety of research and community organizing skills together as they become instruments for social change.

The lesson here may be that those who wish to foster a corporate praxis rhythm of actionreflection need to attend intentionally to communal action dynamics from the start. Faithsharing groups may always remain reflective and focused on individual connections to daily living unless their facilitators and religious educators lead them out into the world of communal action. This shift will also require a systemic approach to religious education that weaves religious and educational concerns into pastoral planning and mission-oriented ministries in the congregation.

\section{Systemic Approaches to Religious Education}

In 1982, Jack Seymour and Donald Miller observed that the typical experience of religious education in congregations has been one where "education is segmented from the total life of the church" (155), primarily into church school and other educational programs. They further warned, "such a separation of education and ministry ignores crucial tasks in the life of the congregation" (155-156). Ministry and religious education often remain in two separate orbits, without convergence.

One attempt to break out of this mold and offer a new approach to religious education was offered by Timothy Lines in his seminal work, Systemic Religious Education (1987). Lines described the paradigm shift involved in "systems" thinking from a variety of perspectives and then used eight salient properties of open systems to outline the contours of a new approach to religious education. Based upon an open systems paradigm, systemic religious education would be (1) holistic, (2) differentiated in its role, (3) conscious of boundaries where religious education interfaces with other functions and activities, (4) dynamic, (5) aware that there are many paths to accomplishing the same goal (i.e., principle of equifinality), (6) cybernetic in its use of continual feedback, (7) transformative of "the heritage of the past into an actualized future" (225), and (8) focused on growth (1987, 221-225). While Lines presents the theoretical underpinnings of systems theory in depth, his work does not include concrete descriptions of how systemic education would actually work in congregational settings. He acknowledged that the application of his theoretical model was left as future work.

In a similar framework, Françoise Darcy-Berube described a current paradigm shift in religious education as moving toward a more holistic and pastoral approach in Christian congregations $(1995,17)$. She noted that various authors in the 1980s and 1990s described the purpose of religious education as focusing on ongoing conversion; teaching the mind, heart, and soul; educating for wisdom; or educating of personal and social transformation. Each of these descriptions points to a more "holistic" understanding of religious education (18). The shift to a more pastoral approach in religious education, notes Darcy-Berube, is characterized by an emphasis on integration of religious education with other ministries and cooperation among all pastoral leaders and religious educators in the church setting. She affirms that "in this approach the primary educator is or should be the parish community" (19). Viewing the parish as a whole system, she further asserts, "a pastoral approach to religious education would require ongoing, organic, dynamic, cooperation between all sectors of parish life" $(1995,34)$. Thus, in her 
descriptions Darcy-Berube is advocating one expression of what Timothy Lines describes as systemic religious education.

Darcy-Berube suggests two structural changes in congregations that would be needed to foster a more holistic and pastoral approach to religious education. One follows the recommendations of Patrick Brennan and calls for all committees, councils and parish structures to become praxis-oriented communities, where theological reflection becomes a regular part of gathering and work time $(1995,36)$. The second involves better coordination of leadership structures in long-range planning for the parish's mission and ministries. Religious education would be woven throughout each of these parish activities.

\section{Learning Organizations: Systems of Corporate Learning}

In 1990, Peter Senge open the floodgates of new research and writings on learning organizations by introducing five necessary disciplines for organizations "where people continually expand their capacity to create the results they truly desire, where new and expansive patterns of thinking are nurtured, where collective aspiration is set free, and where people are continually learning how to learn together" (Senge, 1990, 3). As organizational consultants, primarily working out of MIT's Sloan School of Management, Senge and his associates developed processes to help a variety of business, educational, and service organizations learn the critical skills needed to clarify their collective optimal vision of the future and work effectively to realize it. The five disciplines Senge introduces in his first work, The Fifth Discipline (1990), work together synergistically to help organizational members develop a shared vision of the future and develop new capacities for realizing their dreams.

Personal Mastery is "the discipline of continually clarifying and deepening personal vision" (7). Senge sees this discipline as the "essential cornerstone" of the learning organization and its "spiritual foundation" (7). The organization's energy for learning is based largely on helping people discover their innermost ideals and values and connecting those with the direction and vision of the organization. Persons skilled in the discipline of personal mastery not only can articulate their values and personal aspirations clearly but also can see and interpret their current realities accurately and develop the capability to move effectively toward their envisioned goals.

A second engine for change and learning is the discipline of building shared vision. The emphasis here is on "shared" and differs strikingly from organizations in which a "vision statement" is written by a few leaders and then distributed to members. This second discipline requires large group processes that foster a shared ownership in the concrete directions and plans of the organization. Senge writes:

The practice of shared vision involves the skills of unearthing shared 'pictures of the future' that foster genuine commitment and enrollment rather than compliance. In mastering this discipline, leaders learn the counterproductiveness of trying to dictate a vision, no matter how heartfelt (Senge, 1990, 9).

To reach such energizing shared visions requires critical thinking and the discipline of putting our conceptions of the world at risk in conversation. This discipline Senge calls unearthing mental models. Wherever organizational members gather together, this discipline encourages their engagement in "learningful conversations" $(1990,9)$ where members discover 
their underlying assumptions and worldviews and explore them in mutual trust. As Senge puts it, "The discipline of working with mental models starts with turning the mirror inward; learning to unearth our internal pictures of the world, to bring them to the surface and hold them rigorously to scrutiny" (9).

Senge also advocates an emphasis on team learning in the praxis movements of organizational life. In teams (or in congregation life, communities), members in dialogue begin learning and thinking together with respect to the issues and challenges they must face in actualizing their mission and vision. Team learning also focuses on understanding the dynamics of healthy group processes and recognizing the "patterns of defensiveness" that can undermine learning (10).

Finally the fifth discipline, systems thinking, helps all the learning organization disciplines work together as "an ensemble" (Senge, 1995, 12). It enables organizational members to see not only the big picture but also the underlying dynamics that create current situations and keep the status quo in place. Systems thinking "is the discipline that integrates the disciplines, fusing them into a coherent body of theory and practice" (12).

Senge and his colleagues (1994) have developed a fieldbook of strategies and organizational exercises to help members of organizations learn and appreciate the dynamic interplay among the learning organization disciplines. Their intervention strategies involve simulation exercises and educational processes for individuals, team, and the organization as a whole.

\section{Learning Organizations as a Systemic Framework for Religious Education}

The advantage of using the learning organization disciplines as a conceptual framework for religious education is that they offer a more specific approach to systemic learning than the general principles offered by Timothy Lines, although Lines' work clearly outlines the implications of "systems thinking" for religious education. Each of the disciplines can be fostered and developed throughout the various sub-systems of congregations, and they provide a more explicit map for the work of religious educators who seek to develop communities-inpraxis.

One clear implication of this model is that religious educators and pastoral planners will need to work more closely together in weaving educational processes into planning processes. As collaborators, religious educators and pastoral planners will need to move out of their "silos" (Hawkins, 1997, 48) and cooperate in designing and facilitating various processes in congregations, leading to action and also incorporating wisdom from the rich Christian tradition. This would overcome a weakness in pastoral planning models as well, especially where congregation members are brought together to "dream" together and develop long-range plans for a congregation without learning more about the mission of church and its role in the world and neighborhood in the process of planning. Pastoral planners and consultants, such as Thomas Hawkins (The Learning Congregation, 1997) and Jim Herrington et al. (Leading Congregational Change, 2000) have adopted many of the learning organization principles developed by Senge and his colleagues and have begun to incorporate a systemic educational focus to their ongoing congregational development activities.

Religious educator Jane Regan cautions, however, that the development of community in church settings involves much more depth than learning organizations require. Community entails foundational stories, historical dramas, memories, and embodying convictions. 
Organizations and communities are not interchangeable (Regan, 2002, 120-121). Still, she does advocate Senge's learning organization model as a framework for adult faith formation in parishes and believes the model can be adapted readily to deepening the vision and action of faith communities as a whole (2002, 113-169).

In many respects, the persistence of a Christian vision of mission and ministry in the world shows that the Christian community has for centuries fostered at least some of the principles now named as learning organization disciplines. The explicit identification of these disciplines as crucial to the capacity for effective communal praxis, however, helps the community become more intentional in developing them. In that task, religious education plays a central role.

\section{Religious Educators: Catalysts for Creating Learning Organizations}

From a learning organization (or learning congregation) perspective, religious educators will not be primarily focused on transmitting the faith to individuals nor on forming faith-sharing communities but rather on helping congregations actualize their shared vision of mission by learning and increasing their capacity for wise, intentional, and biblically informed action. This means that religious educators will need to help congregational members read the "signs of the times" clearly with increasing sensitivities to the dynamics at play as they interpret and analyze situations of concern. Religious educators will also help teams and communities learn more about the Christian tradition, its vision of the reign of God, and its guidance for action, with increasing awareness of the sociocultural and literary contexts of the biblical and theological texts chosen. Opportunities will need to be created for individuals, ministry communities, and the congregation as a whole to both reflect on their vision and values and the situations that are presenting themselves for attention and action. As Steven Covey recommends for effective leaders, religious educators will begin with the "end in mind"(1989, 97-98) and help congregational members envision what their commitment to the reign of God means in terms of goals and action plans.

Personal, small community, and large congregational learning form the matrix of religious education activities in learning congregations. On a personal level, an example of religious education related to the discipline of "personal mastery" can be found in Holy Family Catholic Church in Inverness, IL, a parish whose pastor is consultant Rev. Patrick Brennan. There parishioners are invited to participate in a series of prayerful workshops to discern their personal gifts and calling for ministry. The sessions involve reflections on a theology of lay ministry as well as experiential exercises and reflection to help individuals discover their passions for action, gifts, and desires for growth. Upon completion of the sessions, parishioners are invited to channel their newly found enthusiasm and gifts into one of the many ministries sponsored by the parish.

St. John's Parish in Edinburgh, Scotland provides an example of a liturgy committee becoming a "learning community" as it prepared to guide the congregation's process of designing a new worship space in the church. The "committee" began its task by reading Vatican II and later documents on liturgy, art and environment in worship, and ecclesiology. It then designed several processes to work with the entire congregation in summarizing key insights from those documents and obtaining input for the planning process. The end point was not only a new worship space but also a more liturgically aware congregation in its gatherings for communal prayer. 
Norman Cooper offered some ideas for congregation-wide strategic planning that incorporated religious education in his book, Collaborative Ministry: Communion, Contention, Commitment (1993). In developing a church mission statement, Cooper proposes that the entire community of baptized be engaged in developing and owning their "local expression of the universal vision and mission of the church $(1993,70)$. Often it is helpful if an external consultant is brought in to help the pastoral team members and parish council (or other governing bodies of a congregation) reflect together on their ecclesiology and vision of leadership. The leadership community, in turn, is responsible for educating the parish on the importance and purpose of claiming a church mission statement. Homilies and other public forums can become conduits for emphasizing a mission-oriented ecclesial vision and the central importance of mission in church life. Cooper suggests that the pastoral leaders of the congregation work together to organize the entire congregation into home-based learning groups of about ten participants each. Registered members of the congregation receive a letter explaining the process of planning and asking them to read and reflect upon one or more documents related to the mission of the church that will help them prepare for their own congregation's mission-planning. They are also asked to participate in four two-hour meetings in the home-based groups. In these sessions, participants both learn about and reflect on mission and its relation to the reign of God. They also reflect on their own congregation and neighborhood situations, and they offer specific proposals for statements to be incorporated into the parish mission statement. A facilitator who has been selected and prepared for leading the group process guides the home-based groups in accomplishing their tasks. After the leadership team collates the results of the group discussions and drafts a mission statement, the entire congregation gathers in a parish assembly to rework and approve the mission statement (more than one assembly may be needed). The result is not simply a "mission statement." Rather, it is a congregation that shares a sense of mission. Similar processes are used for planning goals and ongoing ecclesial development (1993, 100-143).

Religious educators clearly have a distinct role to play in planning processes that lead congregations and their sub-communities into the action-reflection mode of communal praxis. As experts in the educational resources available, they can help leadership teams choose educational materials appropriate for participants of all ages that are relevant to the activities and tasks of various church communities. Their expertise in designing processes for reflection, raising critical questions, and developing skilled facilitators who can help communities become more dialogical in their "team learning" disciplines are critical to the emergence of learning organization dynamics in congregations. They can also suggest data gathering and social analysis processes for helping the congregation read and interpret situations in their neighborhoods and wider community. Finally, religious educators can help leaders and congregation members alike discover hidden aspects of the Christian tradition that shed new light on what fidelity to the reign of God might mean in the specific situations the community encounters in our rapidly changing world.

Religious educators, well steeped in the discipline of systems thinking, will be able to see their distinctive role in the collaborative processes of pastoral planning, mobilizing congregational members for action, and resourcing communities for their reflection on praxis. With action on behalf of the reign of God in mind, these educational leaders can become true catalysts for communities-in-praxis and for the social transformation that such empowered communities will certainly effect. 


\section{REFERENCES}

Boys, Mary. 1989. Educating in Faith: Maps and Visions. Kansas City: Sheed and Ward.

Coe, George Albert. 1929. What is Christian Education? New York: Scribner, 1929.

Cooper, Norman P. 1993. Collaborative Ministry: Communion, Contention, Commitment. Mahwah, NJ: Paulist.

Covey, Stephen. R. 1989. The Seven Habits of Highly Effective People. New York: Simon and Schuster.

Goizueta, Roberto. 1995. Caminémos con Jesús. Maryknoll, NY: Orbis.

Herrington, Jim; Bonem, Mike, and Furr, James H. 2000. Leading Congregational Change. San Francisco: Jossey-Bass.

Leo XIII. Rerum Novarum.1891. http://www.vatican/va/holy father/leo xiii/encyclicals/documents/hf_1-xiii_enc_15051891_rerum-novarum_en.html

Hawkins, Thomas R. 1997. The Learning Congregation: A New Vision of Leadership. Louisville, KY: Westminster John Knox.

Lee, Bernard J., S.M. 2000. The Catholic Experience of Small Christian Communities. Mahwah, NJ: Paulist.

Lines, Timothy Arthur. 1987. Systemic Religious Education. Birmingham, AL: Religious Education Press.

“Our Mission and Justice," 1995. Documents of General Congregation 34 of the Society of Jesus. St. Louis: Institute of Jesuit Sources.

Regan, Jane. 2002. Toward an Adult Church: A Vision for Faith Formation. Chicago: Loyola Press.

Religious Education Association. 1906. "The Purpose of the Association," Religious Education Vol. 1,2.

Senge, Peter M. 1990. The Fifth Discipline: The Art and Practice of the Learning Organization. New York: Doubleday/Currency.

Senge Peter M. et al. 1994. The Fifth Discipline Fieldbook: Strategies and Tools for Building a Learning Organization. New York: Doubleday/Currency. 
Seymour, Jack L. and Miller, Donald E. 1982. Contemporary Approaches to Christian Education. Nashville, Abingdon.

Tracy, David. 1975. Blessed Rage for Order. New York: Seabury.

Wimberly, Anne E. Streaty. 2003. "Daring to Lead with Hope: Association of Professors and Researchers in Religious Education Presidential Address, November 3, 2002." Religious Education, 98 (3): 277-295. 